\title{
PENONTON ANAK DAN REMAJA TERKAIT PROGRAM ACARA INDONESIAN IDOL JUNIOR 2016: STUDI RESEPSI PADA KONTESTAN ANAK YANG MENYANYIKAN LAGU-LAGU ORANG DEWASA
}

\section{CHILDREN AND TEENAGERS SPECTATORSHIP ABOUT INDONESIAN IDOL JUNIOR 2016: CHILDREN SINGING ADULT'S SONG RECEPTION STUDY}

\author{
Anna Puji Lestari \\ (annapujilestari@gmail.com) \\ (Magister Ilmu Komunikasi, FISIP, UNDIP)
}

\begin{abstract}
Abstrak
Penelitian ini mengkaji pemaknaan penonton anak-anak dan remaja mengenai kontestan anak yang menyanyikan lagu dewasa pada talent show Indonesian Idol Junior 2016. Paradigma yang dipakai dalam penelitian ini adalah paradigma kritis melalui pendekatan kajian budaya. Teori kritis yang digunakan dalam penelitian ini adalah teori Komodifikasi Vincent Mosco untuk menunjukkan Indonesian Idol Junior mengeksploitasi para kontestannya. Metode yang digunakan dalam penelitian ini adalah analisis resepsi. Analisis resepsi mencoba membongkar berbagai interpretasi atas isi media oleh sejumlah kecil penonton atau pembaca (Downing, 1990: 162). Berdasarkan hasil penelitian, anak usia Sekolah Dasar (SD) rentan terkena dampak negatif media. Representasi tayangan televisi yang menampilkan anak-anak menyanyi lagu dewasa bagi seorang informan (SD) dimaknai secara dominan, dan bagi tiga responden lainnya dimaknai secara negosiasi (SMP, SMA). Artinya, siswa SMP dan SMA memiliki struktur pengetahuan yang memadai. Hasil penelitian juga menyatakan bahwa seluruh informan (SD, SMP, SMA) belum memiliki struktur pengetahuan mengenai industri penyiaran.
\end{abstract}

Kata Kunci: Komodifikasi, Eksploitasi, Indonesian Idol Junior

\begin{abstract}
This research examines about interpretation of teenagers and childrens spectatorship about contestants Indonesian Idol Junior 2016 who sang adult's song. This research used critical paradigm through cultural studies approach. Critical theory used in this research is commodification theory of Vincent Mosco to show that Indonesian Idol Junior exploit the contestants. The method is reception analysis which dismantle various interpretations of media content by small number viewers (Downing, 1990: 162). Based on research results, Elementary School Children are vulnerable to the media negative impact. Representation of television shows about children singing adult songs for an informant (Elementary School) is interpreted by dominan reading, and the three other respondents interpreted as negotiation readers (Junior and Senior High School). It means that Junior and Senior High School Students have adequate knowledge structure. The result also stated that all informants do not have knowledge about commodification broadcasting industry.
\end{abstract}

Keywords: Commodification, Exploitation, Indonesian Idol Junior

\section{Pendahuluan}

Program pencarian bakat anak belakangan ini terus menerus diadakan oleh stasiun televisi. Menyanyi merupakan bakat yang paling sering disasar stasiun televisi untuk dijadikan tontonan. Persaingan stasiun televisi untuk merebut hati pemirsanya semakin ketat kian harinya. Menjamurnya acara jenis

pencarian bakat bukannya tanpa sebab. Angka rating yang dihasilkan oleh acara jenis ini selalu tinggi dan dapat bertahan pada rentang waktu yang panjang. Hal ini kemudian membuat stasiun televisi tak hentinya menggelar kontes menyanyi. Indonesian Idol Junior 2016 misalnya, tayang di MNC TV. Survei dari AGB 
Nielsen menyebutkan, tayangan tersebut meraih rating 3.8 persen dan share 21,1 persen.

Tayangan pencarian bakat anak tak hanya Indonesian Idol Junior, ada juga The Voice Kids Indonesia. Pada Desember 2016 tayangan tersebut sudah habis masa tayangnya. Selain itu, perolehan ratingnya pun tak setinggi Indonesian Idol Junior. The Voice Kids Indonesia yang tayang di RCTI pada episode blind audition ratingnya stabil dengan share di atas 20 persen. Namun, memasuki babak-babak selanjutnya, peforma rating terus menurun tidak stabil (http://www.duniatv.net/2016/10/thevoice-kids-indonesia-jadi-program.html, akses tanggal 17 Januari 2017). Itulah alasan yang mendasari mengapa penelitian ini memilih talet show Indonesian Idol Junior 2016.

Indonesian Idol Junior 2016 merupakan kelanjutan dari Indonesian Idol Junior 2014. Program pencarian bakat ini dikhususkan bagi anak-anak berusia 5-13 tahun, dari berbagai kota di Indonesia yang telah lolos audisi. Banyak keuntungan yang bisa diraup sekaligus oleh stasiun TV sebagai penyelenggara. Rating yang tinggi tentu menarik minat banyak perusahaan untuk memasang iklan di waktu acara tersebut ditayangkan. Bahkan, tak sedikit produk yang mensponsori tayangan tersebut. Tidak mengherankan apabila stasiun TV kemudian menyediakan waktu yang panjang untuk acara ini, hingga dibuat Indonesian Idol Junior 2016.

Walaupun acara ini ditujukan bagi anak, kenyataannya acara ini memiliki sasaran pemirsa bebas, semua umur bisa menontonnya. Konsep program ini bisa meraup untung dari penilaian pemirsa terhadap peserta. Pasalnya, program ini memberlakukan penilaian terbuka oleh pemirsanya. Sistem penilaian ini memanfaatkan layanan pesan singkat dan telepon dengan tarif premium. Ribuan hingga ratusan ribu setiap harinya penonton mengirim dukungan untuk idolanya yang sedang berkompetisi.

Logika pasar memainkan peran utama, semakin panjang epsiodenya maka semakin banyak iklan maupun dukungan pemirsa yang masuk, berarti menambah income yang dihasilkan sebuah program. Langkah ini tentu saja merugikan pemirsa yang setia pada peserta favoritnya. Namun, stasiun televisi sebagai industri tak segan melakukan hal ini terus menerus kepada pemirsanya yang menggandrungi ajang adu bakat ini.

Indonesian Idol Junior disebut-sebut sebagai tayangan 'sehat' yang sesuai dengan usia anak. Ini terlihat dari salah satu syarat peserta audisi adalah tidak berpenampilan dewasa, mengenakan pakaian yang colorful atau kostum seperti: superhero, princess, bajak laut, peri, kostum hewan, pakaian daerah/profesi (http://indonesianidoljunior.com/syaratdan-ketentuan-indonesian-idol-junior akses 17 Januari 2017). Namun, pada kenyataannya acara tersebut sama saja dengan talent show yang lain: mencederai hak anak.

Pada Indonesian Idol Junior 2016, kontestan diarahkan menyanyikan lagu bertema cinta, perselingkuhan, dan patah hati. Hal ini tentu bertentangan dengan karakter anak-anak yang ceria. Anak-anak belum waktunya mengetahui cinta ala orang dewasa, apalagi perselingkuhan dan patah hati. Adi Bing Slamet, mantan artis cilik, kecewa dengan hilangnya identitas musik anak-anak di Tanah Air saat ini. "Seandainya ada acara di televisi bobotnya pun tidak ada. Sekarang banyak anak-anak yang menyanyikan lagu milik orang dewasa," kata Adi (Adi Bing Slamet: Industri Musik Anak Sudah Mati, http://www.viva.co.id/prancis2016/read/46 2906-adi-bing-slamet-industri-musik-anaksudah-mati, akses tanggal 25 Desember 2016, pukul 23.35 WIB).

Bahkan, Wakil Gubernur Daerah Istimewa Yogyakarta, Pakualam $\mathrm{X}$, membenarkan bahwa lagu anak telah 
punah. "Kita semua tahu bahwa lagu anak-anak telah punah bak ditelan bumi," ungkapnya (Wagub DIY PA X: Lagu Anak-anak Telah Punah, http://www.jogjalive.com/wagub-diy-pa-Xlagu-anak-anak-telah-punah/, akses tanggal 25 Desember 2016, pukul 23.42 WIB).

Anak-anak menyanyikan lagu dewasa merupakan bentuk eksploitasi, bertentangan dengan Undang-Undang Nomor 23 Tahun 2002 tentang Perlindungan Anak (Lembaran Negara Republik Indonesia Tahun 2002 Nomor 109, Tambahan Lembaran Negara Republik Indonesia Nomor 4235); yakni pasal 66 (c). Pasal tersebut menyatakan perlindungan khusus bagi anak, berbunyi, "Pelibatan berbagai perusahaan, serikat pekerja, lembaga swadaya masyarakat, dan masyarakat dalam penghapusan eksploitasi terhadap Anak secara ekonomi dan/atau seksual." (UU Nomor 35 tahun 2014 Tentang Perubahan Atas Undang-Undang Nomor 23 Tahun 2002 Tentang Perlindungan Anak, http://www.hukumonline.com, akses 26 Desember 2016, pukul 00.02 WIB).

Kondisi ini juga bertentangan dengan Pasal 28B ayat (2) UUD 1945, "Setiap anak berhak atas kelangsungan hidup, tumbuh, dan berkembang serta berhak atas perlindungan dari kekerasan dan dikriminasi." Hal tersebut juga bertentangan dengan UU No. 32 tahun 2002 tentang Penyiaran Pasal 36 ayat 3. Pasal tersebut menyebutkan, isi siaran wajib memberikan perlindungan dan pemberdayaan kepada khalayak khusus, yaitu anak-anak dan remaja, dengan menyiarkan mata acara pada waktu yang tepat, dan lembaga penyiaran wajib mencantumkan dan/atau menyebutkan klasifikasi khalayak sesuai dengan isi siaran.

Komisioner KPI Pusat bidang isi siaran, Dewi Setyarini mengatakan, siaran televisi harusnya melihat aspek perlindungan terhadap khalayak khusus seperti anak. Isi siaran seharusnya mempertimbangkan perkembangan psikologis anak dan remaja karena tayangan media memiliki pengaruh besar terhadap anak dan remaja dan menentukan seperti apa sikap dan pola pikir mereka (Wajib Bagi Televisi, Tayangakan Siaran Ramah Anak dan Perempuan, https://www.kpi.go.id/index.php/lihatterkini/38-dalam-negeri/33564-programpembinaan-isi-siaran-mengembangkansiaran-ramah-bagi-anak-dan-perempuan, akses 26 Desember 2016, pukul 11.17 WIB).

Selain itu, Komisioner Komisi Perlindungan Anak Indonesia (KPAI) Maria Ulfah Anshor menilai perlu adanya kanal atau program khusus anak dalam tayangan televisi. Menurutnya, hal itu penting agar anak mendapat tayangan yang sesuai dengan haknya sebagai anak (Tayangan Berkualitas Untuk Anak Minim,

http://www.republika.co.id/berita/koran/di daktika/16/02/05/o22e8g5-tayanganberkualitas-untuk-anak-minim, akses 26 Desember 2016 pukul 00.20 WIB).

Arti penting isi siaran televisi yang berkualitas bagi perkembangan anak telah ditegaskan melalui Deklarasi Anak dan Televisi Asia-Pasifik (Declaration on Children and Television in The AsiaPacific) pada tanggal 13 September 1991 terkait dengan tiga persoalan: (1) perkembangan budaya melalui televisi anak, (2) televisi pendidikan untuk anak; kebutuhan akan media pendidikan dan (3) pengembangan strategi untuk kualitas televisi anak-anak (dalam Sunarto, 2009: 105-6).

Anak-anak Indonesia menempati urutan teratas di antara negara-negara di ASEAN untuk urusan menonton siaran televisi terlama. Menurut penelitian, ratarata waktu yang dihabiskan anak-anak Indonesia saat menonton siaran televisi mencapai 5 jam dan bahkan lebih untuk setiap harinya. Adapun negara ASEAN lain hanya 2 sampai 3 jam dalam sehari 
(Anak Indonesia Kedapatan Paling Lama menonton TV, http://www.kpi.go.id/index.php/terkini/309 44-anak-indonesia-kedapatan-paling-lamamenonton-tv, akses tanggal 15 Januari 2017).

\section{Indonesian Idol Junior 2016} menampilkan 16 anak dari berbagai daerah menunjukkan bakat meyanyinya yang luar biasa. Namun, sangat disayangkan bila bakat menyanyi ini dieksploitasi dan diarahkan kreator acara hanya untuk memenuhi selera pasar. Karenanya, menarik untuk diteliti bagaimana anakanak dan remaja memaknai tayangan talent show yang mengeksploitasi kontestannya. Anak-anak bukanlah audiens yang sama sekali tidak berdaya. Menurut Jean Piaget, mulai usia 7-8 tahun, anak mulai kritis terhadap lingkungannya (life space) dan membutuhkan penjelasan konkret dan masuk akal. Ketika memasuki usia belasan tahun, anak mulai dapat berpikir secara abstrak (symbolic) dan pandai memberikan respons dan jawaban alternatif terhadap stimulus, dalam hal ini, persoalan yang dihadapi.

Patricia Palmer (1994) membuat penilaian mengenai variasi sesungguhnya dalam memandang kecenderungan terhadap anak-anak, yang didefinisikan menurut usia, gender, serta kedewasaan fisik dan sosial. Menurutnya, anak-anak adalah audiens aktif, anak-anak mengorganisasi kepemirsaan sebagai bagian dari keseluruhan pengalaman domestik, ia menekankan pada apa yang dilakukan anak-anak dengan kepemirsaan televisi (dalam Burton, 2007: 384).

Sementara itu, paradigma yang dipakai dalam penelitian ini adalah paradigma kritis melalui pendekatan kajian budaya. Cara pandang paradigma ini mengkritik segala bentuk opresi (Grossberg, 2005). Termasuk di dalamnya adalah opresi yang dilakukan industri budaya terhadap minat dan bakat anak.

Teori kritis dicirikan oleh tiga hal yaitu: (1) mencoba memahami taken for granted system, struktur kekuasaan, dan ideologi yang mendominasi dalam kehidupan kemasyarakatan; (2) mengungkap aturan kekuasaan dan kondisi sosial yang opresif untuk menciptakan emansipasi atau kondisi masyarakat yang lebih bebas; (3) adanya upaya secara sadar untuk menyatukan teori dan tindakan (Littlejohn dan Foss, 2008: 46).

Pengertian tindakan mengacu pada tindakan apa yang perlu dilakukan untuk melakukan transformasi dari suatu kondisi awal menuju suatu kondisi akhir yang dikehendaki. Sedangkan istilah 'emansipasi' didefinisikan sebagai kebebasan individu memperoleh akses (Kincheloe dan McLaren dalam Denzin dan Lincoln, 2005: 308). Artinya, melalui pendekatan kritis bisa dilakukan perubahan menuju kondisi ideal yang dikehendaki: lagu anak-anak untuk anak-anak.

Cukup banyak penelitian yang mengkaji mengenai penonton anak-anak dan remaja. Pada bagian ini akan dipaparkan beberapa penelitian untuk menunjukkan posisi penelitian ini di antara penelitian-penelitian yang lain. penelitian yang dilakukan Haejung Paik meneliti mengenai asal mula munculnya film, televisi dan internet pada abad ke-20 yang menjadi input bagi perkembangan anak dan remaja. Hasil penelitiannya menyatakan bahwa tayangan yang dikonsumsi anak-anak dan remaja hanya sebesar 6 persen yang mengandung unsur pendidikan.

Berikutnya adalah penelitian yang dilakukan George Comstock dan Erica Scharrer, meneliti bagaimana remaja menonton televisi yang dipenuhi acara kekerasan. Hasil penelitian menyatakan bahwa acara-acara kekerasan di televisi difilter oleh norma masyarakat, karakter individu, dan pengalaman-pengalaman transisi remaja.

Penelitian yang dilakukan oleh Kaveri Subrahmanyam, Robert Kraut, Patricia Greenfield, dan Elisheva Gross. Meneliti pengaruh video games terhadap 
perkembangan psikologi anak. Hasil penelitian menyatakan bahwa game online berpengaruh signifikan terhadap psikologi dan sosial anak. Semakin banyak bermain video games akan menjadikan anak anti sosial.

Penelitian yang dilakukan David Bickham, John Wright dan Aletha Huston. Meneliti tayangan bagi anak prasekolah (Sesamestreet) yang banyak mengandung kalimat interupsi, banyak jeda iklan, para pemainnya berbicara terlalu cepat dan musik yang tidak teratur. Hasil penelitian menyatakan bahwa anak-anak berkurang daya konsentrasinya setelah menonton tayangan tersebut.

Beberapa penelitian yang dipaparkan di atas, semuanya menggunakan teori uses and gratification. Karenanya, pada penelitian kali ini digunakan teori kritis dan metode analisis resepsi penonton anak-anak. Ini merupakan kebaharuan penelitian. Terlebih, penelitian komunikasi yang melibatkan penonton anak-anak dan remaja jarang dilakukan.

Teori kritis yang digunakan dalam penelitian ini adalah teori Komodifikasi Vincent Mosco. Komodifikasi adalah proses transformasi barang dan jasa dari nilai guna menjadi komoditas yang berorientasi pada nilai tukar di pasar. Berdasarkan pemikiran Mosco, Indonesian Idol Junior 2016 melakukan bentuk komodifikasi konten, komodifikasi khalayak dan komodifikasi buruh (para kontestan dieksploitasi).

Pertama, The Commodification of Content (Komodifikasi Isi) merupakan proses perubahan pesan dari kumpulan informasi ke dalam sistem makna dalam wujud produk yang dapat dipasarkan. Konten Indonesian Idol 2016 direduksi oleh kreator acara hanya sebagai produk yang bisa dipasarkan. Selama tayangan tersebut bisa menarik pemasang iklan sebanyak-banyaknya. Maka, tayangan tersebut akan terus direproduksi. Impilasi komodifikasi isi adalah tidak memperhatikan mutu tayangan. Karena ini tayangan anak-anak, seharusnya mementingkan perkembangan psikologis anak. Kenyataannya, Anak diminta menyanyikan lagu dewasa guna menarik pemirsa sebanyak mungkin dari berbagai usia

Kedua, Commodification of Audiens (Komodifikasi Khalayak) merupakan proses modifikasi peran pembaca/khalayak oleh perusahaan media dan pengiklan, dari fungsi awal sebagai konsumen media menjadi konsumen khalayak selain media. Komodifikasi khalayak yaitu media melakukan pertukaran dengan rating. Komodifikasi ini melekat secara langsung dari program atau acara yang dibuat oleh media. Ini terlihat jelas di Indonesian Idol Junior, anak-anak dituntut menyanyikan lagu dewasa mengikuti selera pasar agar diminati oleh semua kalangan pemirsa guna memperoleh rating tinggi. Rating tinggi akan membuat banyak pemasukan iklan.

Ketiga, commodification of Labor atau komodifikasi buruh. Merupakan transformasi proses kerja dalam kapitalisme, dimana keahlian dan bakat menyanyi anak-anak dijadikan komoditas yang diperjualbelikan. Anak-anak disuruh menyanyi, dipertontonkan sedemikian rupa dengan iming-iming menjadi terkenal (Mosco, 1996: 145-170).

\section{Metodologi}

Pernyataan teoritis yang terdapat dalam penelitian ini lebih mengacu pada konteks lokal spesifik dan menunjukkan keberagaman pemaknaan dan pengalaman penonton anak-anak dan remaja. Penelitian ini berargumen bahwa cara pandang kita mengenai suatu permasalahan yang ada di dalam masyarakat telah terdistorsi oleh hubungan kuasa yang terlibat di dalam konstruksi permasalahan tersebut (Heiner, 2006).

Penelitian ini merupakan penelitian deskriptif yang menggunakan kajian budaya kritis untuk menggambarkan bias sosial pada para proses pemaknaan teks 
(produk televisi): Indonesian Idol Junior 2016. Pendekatan atau metode yang digunakan dalam penelitian ini adalah analisis resepsi. Analisis resepsi mencoba membongkar berbagai interpretasi atas isi media oleh sejumlah kecil penonton atau pembaca (Downing, 1990: 162).

Audiens yang berbeda akan membaca teks yang berbeda dengan cara yang berbeda pada saat yang berbeda. Pandangan audiens sentris terhadap televisi akan melihat makna sebagai sesuatu yang diciptakan dalam pemikiran pemirsa melalui interaksi dengan program tayangan televisi (Burton, 2011: 47).

Metode analisis resepsi berdasarkan encoding/decoding Stuart Hall. Teori encoding/decoding mendorong terjadinya interpretasi yang beragam dari teks media selama proses produksi dan penerimaan (resepsi). Tiga interpretasi yang berbeda dikenalkan oleh Hall antara lain: pertama, yang disebut dengan posisi dominanhegemoni (dominant-hegemonic position) di mana penonton yang menerima program tayangan televisi menerima begitu saja (secara penuh) ideologi dominan dari program acara tanpa ada penolakan atau ketidaksesuaian.

Kedua, disebut dengan posisi negosiasi (negotiated code). Menjelaskan penonton mencampuradukkan interpretasinya dengan pengalaman sosial tertentu yang mereka alami. Penonton yang masuk dalam kategori ini bertindak antara adaptif dan oposisi terhadap interpretasi pesan.

Ketiga, adalah posisi oposisi (oppositional code). Terjadi ketika penonton berlawanan dengan representasi yang ditayangkan dalam tayangan televisi dengan cara pemaknaan berbeda dari yang ditawarkan kreator acara. Makna dominan yang ditawarkan kreator acara disebut preferred reading.

Makna domian yang ditayangkan oleh Indonesian Idol Junior meliputi tiga kode utama. Pertama, kode juri: juri digambarkan memberi masukan dan kritik bagi kontestan anak-anak secara wajar. Kedua, kode mutu tayangan: Indonesian Idol Junior digambarakan sebagai tayangan pencarian bakat yang menghargai talent anak-anak. Ketiga, kode kontestan anak menyanyi lagu dewasa: tidak masalah anak-anak menyanyi lagu dewasa karena itu bisa menarik penonton dari segala usia.

Teknik pengambilan sampel dilakukan dengan purposive sampling, yaitu teknik pengambilan sampel tidak secara acak, tetapi dipilih dengan sengaja pada informan yang memenuhi kriteria sesuai dengan kebijaksanaan peneliti. Dengan strategi maximum variation sampling, bertujuan menjangkau permasalahan secara luas untuk memperoleh variasi dimensi-dimensi kepentingan dan nilai guna menyesuaikan dengan berbagai kondisi berbeda (Patton, 2002: 243). Penelitian ini menjadikan anak-anak dan remaja berusia $10-16$ tahun yang menonton Indonesian Idol Junior 2016 sebagai subjek penelitian. Selain dimaksudkan untuk memperoleh keberagaman data dari subjek yang diteliti, pembatasan usia tersebut dipilih karena hal tersebut juga akan berpengaruh terhadap kemampuan subjek dalam memahami serta mengungkapkan resepsinya tentang fenomena anak-anak menyanyikan lagu dewasa. Dengan demikian, berdasarkan Maximum variation (heterogeneity) sampling, akan dipilih subyek penelitian yang masing-masing mewakili beragam penonton anak dan remaja berdasarkan variasi sebagai berkut: (1) Pendidikan SMA dua orang, (2) Pendidikan SMP satu orang, (3) Pendidikan SD satu orang. Total responden berjumlah 4 orang.

\section{Hasil dan Pembahasan}

Terdapat tiga kode dominan yang bisa ditelusuri dalam Indonesian Idol Junior 2016 yaitu: kode juri, kode lagu dewasa dinyanyikan anak, kode mutu tayangan Indonesian Idol Junior 2016. 
1. Kode Juri

Juri-Juri dalam Indonesian Idol Junior 2016 adalah Daniel Mananta (Voice Jockey Dewasa), Vidi Aldiano (Penyanyi lagu Pop Dewasa), Riafinola Ifani Sari (Penyanyi dari Grup AB Three). Pada salah satu episode Indonesian Idol 2016 yang tayang pada 25 Desember 2016 di MNC TV, salah satu Juri, Vidi Aldiano, berkomentar pada salah satu kontestan anak (laki-laki) yang bersuara bagus. Berikut komentarnya, "Kamu keren banget, kayak Ariel Noah. Cewek-cewek kalau lihat kamu pasti langsug teriak awwwww!!!" Komentar tersebut, tentu saja tidak pantas ditujukan bagi anak yang seharusnya masih fokus belajar untuk masa depan, bukan untuk menarik perhatian lawan jenis.

Komentar spontan yang dilontarkan juri tersebut tidak pantas karena tidak mempertimbangkan aspek moralitas bagi anak. Kahadiran Juri dalam tayangan tersebut merupakan perwujudan komodifikasi tayangan anak. Tayangan anak bukan ditujukan bagi anak karena nilai gunanya, tapi ditujukan bagi pasar karena nilai tukarnya yang fantastis bagi pelaku industri media. Anak-anak sebagai generasi penerus bangsa dieksploitasi dan sangat dirugikan dalam hal ini.

Berikut adalah pemaknaan para informan mengenai Juri dalam Indonesian Idol Junior 2016. Satu orang informan yang duduk di bangku Sekolah Dasar (SD) kelas 4 menyatakan bahwa jurinya baik dan wajar dalam kapasitasnya sebagai juri. Ini artinya, informan melakukan pembacaan dominan (dominant-hegemonic position). Posisi ini terjadi ketika produsen acara menggunakan kode-kode yang bisa diterima secara umum, sehingga penonton akan menafsirkan dan membaca pesan/tanda itu dengan pesan yang sudah diterima secara umum tersebut. Untuk situasi ini, dapat dikatakan tidak terjadi perbedaan penafsiran antara produsen dengan penonton (Hall dalam Hall, Hobson, Lowe dan Willis, 1986: 129-138).
Penonton memaknai teks sesuai yang ditawarkan media (preferred reading).

Satu orang informan yang duduk di bangku SMP kelas 1 menyatakan bahwa komentar-komentar juri tersebut terlalu menyakitkan, sangat tidak pantas bagi kontestan Indonesian Idol Junior 2016 yang masih anak-anak. Informan ini melakukan pembacaan oposisi (oppositional code/position). Pembacaan ini terjadi apabila penonton menandakan secara berbeda atau membaca secara berseberangan dengan apa yang ingin disampaikan oleh kreator acara. Pembacaan oposisi ini muncul ketika penonton menggunakan kerangka budayanya sendiri (Hall dalam Hall, Hobson, Lowe dan Willis, 1986: 129-138).

Dua orang informan yang berstatus sebagai pelajar SMA kelas X menyatakan jurinya banyak memberikan pujian jadi bisa menjadikan motivasi bagi kontestannya. Mereka juga menyatakan bahwa juri memang harus memberi masukan bagi kontestan yang kurang bisa menguasai panggung, bukan hanya memuji. Pemahaman para informan tersebut membawa mereka pada pemaknaan Dominan-hegemonic. Mereka memaknai juri Indonesian Idol Junior 2016 sesuai dengan makna yang ditawarkan kreator acara: Juri harus menarik, memuji dan memberi saran.

2. Kode Lagu Dewasa Dinyanyikan Anak-anak

Anak-anak seharusnya menyanyikan lagu anak yang ceria dan mengandung pesan moral. Lewat musik, anak akan lebih kreatif. Musik dipercaya mampu menstimulus kecerdasan otak karena sebagai sarana belajar dan bermain. Kontestan anak Indonesian Idol Junior lebih fasih menyanyikan lagu bertema cinta, perselingkuhan, dan patah hati. Hal ini tentu bertentangan dengan karakter anak-anak yang ceria. Anak-anak belum waktunya mengetahui cinta ala orang dewasa, apalagi perselingkuhan dan patah hati. 
Berikut adalah pemaknaan para informan mengenai kontestan anak menyanyi lagu dewasa di Indonesian Idol Junior 2016. Informan yang duduk di bangku SD menyatakan kontestan yang menyanyikan lagu tersebut dinilai lumayan bagus suaranya. Ia juga dengan tegas menyatakan setuju bila anak-anak disuruh menyanyi lagu dewasa karena enak didengar. Ini artinya, informan melakukan pembacaan dominan-hegemonik. Ia mengamini sepenuhnya makna yang ditawarkan kreator acara: tidak masalah anak-anak menyanyi lagu dewasa, yang penting saya suka.

Berikutnya, informan yang duduk di bangku SMP. Menurutnya lagu yang dinyanyikan para kontestan bagus, tetapi lebih bagus lagi mereka menyanyikan lagu anak-anak karena kontestannya adalah anak-anak. Informan ini berada di posisi negosiasi karena ia menyetujui bahwa lagu yang dinyanyikan bagus di satu sisi. Di sisi lain, menyatakan sebaiknya anak-anak menyanyikan lagu anak-anak.

Dua orang informan yang duduk di bangku SMA, menyatakan bahwa suara para kontestan bagus. Menurut mereka, sebaiknya para kontestan menyanyikan lagu anak-anak, bukan dewasa karena belum saatnya. Namun, menurut mereka, karena ini ajang kompetisi, berarti semua kontestan dituntut bisa menyanyikan lagu apa saja, termasuk lagu dewasa. Walau mereka lebih menyarankan agar anak-anak menyanyi lagu anak. Artinya, informan berada dalam posisi negosiasi, memaknai teks sesuai kondisi kultural yang dialami dan diyakininya,

3. Kode Mutu Program Indonesian Idol Junior 2016

Indonesian Idol Junior disebut kreator acaranya sebagai tayangan bermutu baik karena mementingkan anak dengan cara memfasilitasi bakat menynyi anak. Kenyataannya, acara tersebut justru mencederai hak anak untuk mendapatkan tontonan yang sesuai usianya. Berdasarkan analisa Komodifikasi dari Vincent Mosco, ada tiga komodifikasi (orientasi selera pasar) yang dilakukan Indonesian Idol Junior. Pertama, komodifikasi isi: tidak memperhatikan mutu tayangan. Karena ini tayangan anak-anak, seharusnya mementingkan perkembangan psikologis anak. Kenyataannya, Anak diminta menyanyikan lagu dewasa guna menarik pemirsa sebanyak mungkin dari berbagai usia. Kedua, komodifikasi penonton. Menarik penonton sebanyak mungkin guna meraih rating tinggi untuk menarik banyak pemasang iklan. Ketiga, komodifikasi buruh. Kontestan anak-anak bisa diibaratkan sebagai buruh karena dieksploitasi kemampuan menyanyinya untuk dipertontonkan dengan iming-iming menjadi terkenal.

Berikut adalah pemaknaan para informan mengenai mutu Indonesian Idol Junior. Informan yang duduk di Bangku SD kelas 4 menyatakan bahwa acara Indonesian Idol 2016 bagus karena berisi lagu-lagu (bisa sebagai hiburan). Informan ini berada pada posisi dominan-hegemonik karena melakukan pemaknaan sebagaiama ditawarkan media: Indonesian Idol Junior acara bagus yang memfasilitasi anak menyanyi.

Informan berikutnya, duduk di bangku SMP kelas 1. Ia menyatakan bahwa Indonesian Idol Junior 2016 merupakan acara yang menarik karena kontestannya lucu-lucu, imut, cantik dan bagus suaranya. Informan tersebut melakukan pemaknaan dominanhegemonik: memaknai sesuai pemaknaan yang ditawarkan media (kreator acara).

Dua orang informan yang berstatus sebagai pelajar SMA kelas X menyatakan bahwa acara Indoensian Idol Junior 2016 adalah acara yang bagus. Acara ini dinilai bisa memotivasi anak-anak lain untuk mengembangkan bakatnya menyayi. Ini artinya, dua orang tersebut juga melakukan pemaknaan secara dominanhegemonik. 


\section{Penutup}

Berdasarkan hasil penelitian, dapat disimpulkan bahwa anak usia Sekolah Dasar rentan terkena dampak negatif media. Sehingga, diperlukan literasi media sejak dini bagi anak-anak, yakni bagi anak-anak usia Sekolah Dasar. Semakin awal semakin baik bagi anak dikenalkan literasi media untuk memaksimalkan perkembangan afektif. Perkembangan afektif merupakan dasar perkembangan manusia. Erikson mengemukakan bahwa perkembangan afektif manusia adalah sintesis dari tugas-tugas perkembangan dan tugas-tugas sosial.

Representasi tayangan televisi yang menampilkan anak-anak menyanyi lagu dewasa bagi seorang informan (SD) dimaknai secara dominan, dan bagi tiga responden lainnya dimaknai secara negosiasi (SMP, SMA). Artinya, siswa SMP dan SMA memiliki struktur pengetahuan yang memadai. Sesuai pendapat Potter yang menyatakan bahwa audiens kritis memiliki struktur pengetahuan yang memadai sehingga memungkinkan mereka membangun relasi dengan media secara proporsional. Struktur pengetahuan inilah yang disebutnya dapat membantu mereka dalam menghadirkan makna pesan yang ditemuinya (dalam Prajanto, 2001: 125).

Pemaknaan mengenai kompetensi Juri dalam Indoneisan Idol Junior 2016, yaitu, tiga informan berada pada posisi dominan-hegemonic (SD, 2 SMA) dan satu orang pada posisi oppositional (SMP). Sebagai pendekatan kultural, analisis resepsi melihat khalayak aktif dalam mengonstruksi makna pesan yang ditawarkan media berdasarkan pendekatan kultural yang dimilikinya, sebagaimana dilakukan informan yang duduk di bangku SMP. Selain faktor pendidikan, faktor kultural bisa menjadi filter bagi tayangan yang rendah mutu. Sebagaimana dinyatakan Stuart Hall, para konsumen teks ini ketika berhadapan dengan sebuah teks, akan memproduksi makna mereka sendiri, berdasarkan latar belakang budaya, pengetahuan, keyakinan, dan ideologi mereka sendiri, yang boleh jadi berbeda sama sekali dengan makna yang ditawarkan media (Hall, 1986: 130-1).

Mutu Indonesian Idol Junior 2016, oleh semua informan dimaknai secara dominan-hegemonik. Artinya, mereka setuju mutlak bahwa Indonesia Idol Junior 2016 adalah acara yang memiliki mutu baik karena mengembangkan bakat menyanyi anak. Artinya, struktur pengetahuan mengenai komodifikasi tayangan belum ada pada semua informan

Hasil penelitian juga menyatakan bahwa seluruh informan (SD, SMP, SMA) belum memiliki struktur pengetahuan mengenai industri penyiaran. Sebagai sebuah industri, dunia penyiaran mengedepankan memeproleh untung dengan menghasilkan tayangan yang mendatangkan iklan sebanyak-banyaknya. Tayangan yang diproduksi hanya dianggap sebagai barang dagangan, bukan tayangan mencerahkan yang mengandung nilai edukasi. Pengetahuan semacam ini perlu diberikan pada anak-anak dan remaja agar mereka jeli memilih tontonan.

\section{Daftar Pustaka}

Burton, Graeme. (2007). Membicangkan Televisi: Sebuah Pengantar Kepada Kajian Televisi. Yogyakarta: Jalasutra.

Burton, Graeme. (2011). Membincangkan Televisi, Sebuah Kajian Televisi. Yogyakarta: Jalasutra.

Downing, John, Mohammadi, Ali, and Sreberny-Mohammadi, Annabelle. (1990). Questioning The Media: A Critical Introduction. California: Sage Publication.

Grossberg, L. (2005). Cultural Studies. Retrieved 11 Januari 2016 from

Hall, Stuart, Dorothy Hobson, Andrew Lowe and Paul Willis (Eds.). (1986). Culture, Media, Language. London: Hutchinson. 
Heiner, R. (2006). Social Problems: An Introduction to Critical Constructionism $(2$ ed). New York: Oxford University Press.

Kincheloe, Joe L. and Mc Laren, Peter. (2005). "Rethinking Critical Theory and Qualitative Research." Dalam Norman K. Denzin and Yvonna S. Lincoln (Eds.), The Sage handbook of Qualitative Research ( ${ }^{\text {rd }}$ ed). USA: Sage Publication.

Littlejohn, Stephen W. and Foss, Karen A. (2008). Theories of Human Communication $\left(9^{\text {th }}\right.$ ed). Belmont, USA: Wadsworth, A Devision of Thomson Learning, Inc.

Mosco, Vincent. (1996). The Political Economy of Communication. Rethinking and Renewal. London: SAGE Publications.

Patton, Michael Quinn. (2002). Qualitative Research and Evaluation Methods. London: Sage Publications, Inc.

Prajarto, Nunung. (2006). Media Komunikasi: Siapa Mengorbankan Siapa. Yogyakarta: FISIPOL UGM.

Sunarto. (2009). Televisi, Kekerasan dan Perempuan. Jakarta: PT Kompas Media Nusantara.

http://www.duniatv.net/2016/10/the-voicekids-indonesia-jadi-program.html, akses tanggal 17 Januari 2017. http://www.hukumonline.com, akses 26 Desember 2016, pukul 00.02 WIB.

http://indonesianidoljunior.com/syaratdan-ketentuan-indonesian-idol-junior akses 17 Januari 2017.

http://www.jogjalive.com/wagub-diy-pa-Xlagu-anak-anak-telah-punah/, akses tanggal 25 Desember 2016, pukul 23.42 WIB.

https://www.kpi.go.id/index.php/lihatterkini/38-dalam-negeri/33564program-pembinaan-isi-siaranmengembangkan-siaran-ramah-bagianak-dan-perempuan, akses 26 Desember 2016, pukul 11.17 WIB.

http://www.kpi.go.id/index.php/terkini/309 44-anak-indonesia-kedapatan-palinglama-menonton-tv, akses tanggal 15 Januari 2017.

http://www.republika.co.id/berita/koran/di daktika/16/02/05/o22e8g5-tayanganberkualitas-untuk-anak-minim, akses 26 Desember 2016 pukul 00.20 WIB

http://www.viva.co.id/prancis2016/read/46 2906-adi-bing-slamet-industrimusik-anak-sudah-mati, akses tanggal 25 Desember 2016, pukul 23.35 WIB. 